\title{
Study of Relative Antioxidant Potential of Induced Variants of Catharanthus roseus (L.) G. Don in Salt Stress Condition for the Effective Selection of Salt Tolerant Variant
}

\author{
Ashutosh Kumar Verma*
}

\section{Ashutosh Kumar Verma*}

Botanical Survey of India, Central Regional Center, 10-Chatham Line, Allahabad, Uttar Pradesh, INDIA.

\section{Correspondence}

Dr. Ashutosh Kumar Verma

Botanical Survey of India, Central Regional Center, 10-Chatham Line Allahabad-211002, Uttar Pradesh, INDIA

E-mail: simashutosh@rediffmail.com

\section{History}

- Submission Date: 14-10-2019;

- Review completed: 23-10-2019;

- Accepted Date: 21-11-2019;

DOI : 10.5530/fra.2019.2.13

Article Available online

http://www.antiox.org

\section{Copyright}

(C) 2019 Phcog.Net. This is an openaccess article distributed under the terms of the Creative Commons Attribution 4.0 International license.

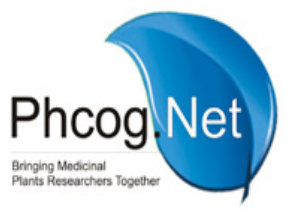

\begin{abstract}
Objectives: Catharanthus roseus (L.) G. Don is an important plant documented for variety of medicinal uses and salt tolerant potential. During genetic improvement programme an attempt of induced mutagenesis was made for isolation of improved genotype of C. roseus var. Nirmal (CIMAP 0865) and nine EMS induced variants were isolated. Present study was made for the assessment of relative antioxidative potential of these variants and identification/selection of salt tolerant genotype. Methods: For the assessment of relative antioxidative potential under glass house condition one month old seedlings of all variants exposed to salt stress condition and the activities of antioxidant enzymes viz., superoxide dismutase, peroxidase and catalase were estimated in leaf tissue at $4^{\text {th }}$ day and $8^{\text {th }}$ day of $\mathrm{NaCl}$ supply while proline and total alkaloid contents were estimated at $8^{\text {th }}$ day of $\mathrm{NaCl}$ supply. Results: In general, $\mathrm{NaCl}$ imposition causes increase in activity of earlier two enzymes, decrease in catalase activity and stimulatory effect on proline and total alkaloid content. Values for these parameters varied with type of variants. Variants V2, V3 and V7 exhibited higher activity of antioxidant enzymes and had high accumulation of proline and total alkaloids. Conclusion: The variants V2, V3 and V7, having higher estimates for these parameters than that of parental variety which indicates their better survival/adaptive potential against salt stress condition and in context of salt tolerant may be utilized in genetic improvement programme of $C$. roseus.

Key words: Antioxidant enzymes, Variants, Catharanthus roseus, Salt stress.
\end{abstract}

\section{INTRODUCTION}

Salinity in soil presents a stress condition for growth and development of the plants. Under natural conditions, plants are inevitably exposed to different types of stresses which may cause increased production of Reactive Oxygen Species (ROS) such as superoxide radical, $\mathrm{H}_{2} \mathrm{O}_{2}$ and hydroxyl radical particularly in chloroplasts and mitochondria. ${ }^{1,2}$ Generation of ROS causes rapid cell damage by triggering off a chain reaction. ${ }^{3}$ Plants under stress produce some defense mechanisms to protect themselves from the harmful effect of oxidative stress. ROS scavenging is one of the common defense responses against abiotic stresses. ${ }^{4}$ ROS scavenging depends on the detoxification mechanism provided by an integrated system of non-enzymatic reduced molecules like ascorbate and glutathione and enzymatic antioxidants. ${ }^{5}$ The major ROS scavenging activities include complex nonenzymatic (ascorbate, glutathione, a-tocopherol) and enzymatic (Super oxide dismutase, Peroxidase and Catalase etc.) responses. ${ }^{6}$ The pathways include the water-water cycle in chloroplasts and the ascorbateglutathione cycle. ${ }^{7}$ Antioxidant mechanisms may provide a strategy to enhance salt tolerance in plants. Among the several approaches to solve the problem of saline soils, the biological approach to identify or grow salt-tolerant plants in such soils to enable soil reclamation is promising. ${ }^{8}$ Considering the above mentioned facts, like crop plants it is also essential to test important medicinal plants for their salinity tolerance and the economic exploitation of saline soils. ${ }^{9}$ Catharanthus roseus (L.) G. Don. is an important medicinal plant of the family Apocynaceae used for treating many fatal diseases and has good antioxidant potential but the salinity effect and antioxidant potential have attributed little attention. ${ }^{8}$ Keeping this view an attempt of induced mutagenesis was made for the isolation/selection of improved genotypes of C. roseus var. Nirmal (CIMAP 0865) which have better salt tolerance potential and nine variants were isolated. This paper reports the findings on antioxidant potential of EMS induced variants of $C$. roseus under salt stress conditions.

\section{MATERIALS AND METHODS}

One month old seedlings of nine EMS induced variants of Catharanthus roseus (L.) G. Don, var. Nirmal, (Table 1) were transplanted in refined sand at

Cite this article: Verma AK. Study of Relative Antioxidant Potential of Induced Variants of Catharanthus roseus (L.) G. Don in Salt Stress Condition for the Effective Selection of Salt Tolerant Variant. Free Radicals and Antioxidants. 2019;9(2):73-7. 
ambient temperature $\left(15^{\circ}-32^{\circ} \mathrm{C}\right)$ under glasshouse conditions in polythene containers (10") and supplied with the basal nutrient solution for about one month. ${ }^{10}$ The composition of the basal nutrient solution was: 4 $\mathrm{mM} \mathrm{Ca}\left(\mathrm{NO}_{3}\right)_{2} ; 4 \mathrm{mM} \mathrm{KNO}{ }_{3} 1 \mathrm{mM} \mathrm{Mg} \mathrm{SO} \mathrm{m}_{4} ; 1.5 \mathrm{mM} \mathrm{NaH}_{2} \mathrm{PO}_{4} ; 0.1 \mathrm{mM}$ $\mathrm{NaCl}$; $0.1 \mathrm{~m} \mathrm{M}$ Fe-EDTA; $10 \mu \mathrm{M} \mathrm{MnSO}_{4} ; 1.0 \mu \mathrm{M} \mathrm{ZnSO}_{4} ; 1.0 \mu \mathrm{M} \mathrm{CuSO}_{4}$; $30 \mu \mathrm{M} \mathrm{H}_{3} \mathrm{BO}_{3} ; 0.2 \mu \mathrm{M} \mathrm{Na}_{2} \mathrm{MoO}_{4} ; 0.1 \mu \mathrm{M} \mathrm{CoSO}_{4}$ and $0.1 \mu \mathrm{M} \mathrm{NiSO}_{4}$. Thereafter, the plants were divided into two lots. One lot was allowed to grow with basal nutrient solution to serve as control while the second lot was grown in the nutrient solution having $200 \mathrm{mM} \mathrm{NaCl}$. Deionized water was used throughout the culture period and contamination of chloride $\left(\mathrm{Cl}^{-}\right)$from any other resource was avoided and nutrient solution was supplied daily. The activities of antioxidant enzymes viz., Superoxide Dismutase (SOD), Peroxidase (POD) and Catalase (CAT) were estimated in leaf tissue at $4^{\text {th }}$ day and $8^{\text {th }}$ day of $\mathrm{NaCl}$ supply while proline and total alkaloid contents were estimated at $8^{\text {th }}$ day of $\mathrm{NaCl}$ supply.

SOD, POD and CAT activities were measured by the method of, Beauchamp and Fridovich, ${ }^{11}$ Luck method ${ }^{12}$ and Euler and Josephson ${ }^{13}$ method, respectively. For expressing the enzyme activity on protein basis, soluble protein content in enzyme extract was measured after precipitation with trichloroacetic acid by the method of Lowry et al. ${ }^{14}$

\section{Table 1: Different type of variants/mutants formed at different concen-} tration of EMS treatment.

\begin{tabular}{|ccc|} 
Variant & Characters & Formed at \\
V1 & Dwarf & $0.50 \%$ EMS \\
V2 & Base branching and high root alkaloid & $0.50 \%$ EMS \\
accumulating variant. & \\
V3 & Early flowering variant. & $0.50 \%$ EMS \\
V4 & Dwarf and low alkaloid accumulating variant. & $0.75 \%$ EMS \\
V5 & Base branching variant. & $0.75 \%$ EMS \\
V6 & Early flowering variant. & $1.00 \%$ EMS \\
V7 & Semi dwarf, seven petaled flower containing & $0.75 \%$ EMS \\
V8 & Early flowering, high leaf biomass yielding & $1.00 \%$ EMS \\
V9 & variant & $1.00 \%$ EMS \\
\hline
\end{tabular}

using bovine serum albumin (Sigma) as standard. Proline content was measured following the method of Bates et al. ${ }^{15}$ Total alkaloid content $(\mu \mathrm{gm} / \mathrm{g})$ estimation in leaf tissue was done by the methodology developed by Narsasimhan et al. ${ }^{16}$ All statistical analysis's were carried out by using STASTICA version 6.0 software.

\section{RESULTS}

Performance of ten genotypes (9 EMS induced variants + parent plant) of C. roseus var. Nirmal were assessed under salt stress condition by studying biochemical parameters viz. activity of SOD, POD, CAT, accumulation of proline and total alkaloid in leaf tissue. Data pertaining results of this experiment are summarized in Table 2, 3 and 4.

Results indicates that in general, imposition of $\mathrm{NaCl}$ stress caused an increase in SOD, POD activity while decrease in CAT activity. At day 4 maximum increase in SOD activity over respective control was noted for variant V2 (227\%) and V7 (227\%) while minimum for V-1 (0.90\%) At day 8 it was noted maximum for V2 (203\%) and minimum for variant V1 (11.2\%). At day 4 maximum increase over respective control values for POD activity was found for V-3 (535\%) and minimum for V9 $(2.5 \%)$ while at day 8 it was maximum for V-7 (486\%) and minimum for V-9 (9.1\%) (Figure 1 and 2).

Catalase activity in all genotypes except for V2, V3, V5 and V7 were decreased at day 4 of $\mathrm{NaCl}$ supply. This decrease was noted maximum for parent plant (-61.8\%) and minimum for V6 (-0.70\%) at day 4 while at $8^{\text {th }}$ day of $\mathrm{NaCl}$ supply decrease in CAT was found in all mentioned genotype except for parent, V2, V3 and V7. It was noted maximum for $\mathrm{V} 9(-32.6 \%)$ and minimum for $\mathrm{V} 8(-0.30 \%)$. Besides this, $\mathrm{NaCl}$ generated salt stress condition also showed stimulatory effect on proline and alkaloid biosynthesis. On $8^{\text {th }}$ day of $\mathrm{NaCl}$ supply maximum increase over respective control values for total proline was found for variant V-7 (439\%) and minimum for parent plant (5.83\%) while total alkaloid content in leaf tissue was noted maximum for variant/ mutant V9 (69.1\%) while minimum for V2 (12.3\%) respectively.

In this study significant increase in SOD activity over parent plant was noted for variant $\mathrm{V}_{2}, \mathrm{~V}_{3}$ and $\mathrm{V}_{7}$ at $4^{\text {th }}$ and $8^{\text {th }}$ day of $\mathrm{NaCl}$ supply whereas, for $\mathrm{V} 2$ and $\mathrm{V} 7$ at day 4 and $\mathrm{V} 9$ at $8^{\text {th }}$ day of $\mathrm{NaCl}$ supply. In general in our study sum up activity of both enzymes (SOD, POD) was noted higher in

Table 2: Activity of antioxidative enzymes in C. roseus leaves in relation to excess $\mathrm{NaCl}$ supply at day 4.

\begin{tabular}{|c|c|c|c|c|c|c|c|c|c|c|c|}
\hline $\begin{array}{l}\text { Treatments/ } \\
\text { Variants }\end{array}$ & Parent & v1 & V2 & V3 & V4 & V5 & V6 & V7 & V8 & V9 & $\begin{array}{c}\text { LSD } \\
P=0.05\end{array}$ \\
\hline & \multicolumn{11}{|c|}{ Superoxide dismutase: } \\
\hline Control & 14.5 & 28.9 & 11.5 & 15.6 & 15.4 & 14.7 & 18.2 & 13.4 & 22.6 & 29.9 & 14.3 \\
\hline $\mathrm{NaCl}$ & $\begin{array}{c}41.6 \\
(+188)\end{array}$ & $\begin{array}{c}29.2 \\
(+0.9)\end{array}$ & $\begin{array}{c}37.5 \\
(+227)\end{array}$ & $\begin{array}{c}31.6 \\
(+103)\end{array}$ & $\begin{array}{c}30.6 \\
(+98.7)\end{array}$ & $\begin{array}{c}24.4 \\
(+66.5)\end{array}$ & $\begin{array}{c}42.7 \\
(+134)\end{array}$ & $\begin{array}{c}43.8 \\
(+227)\end{array}$ & $\begin{array}{c}43.3 \\
(+91.9)\end{array}$ & $\begin{array}{c}36.2 \\
(+21.2)\end{array}$ & 25.7 \\
\hline & \multicolumn{11}{|c|}{ Peroxidase: Difference in OD } \\
\hline Control & 1.84 & 0.49 & 0.50 & 0.20 & 0.55 & 0.54 & 1.32 & 0.33 & 0.88 & 1.19 & 0.37 \\
\hline \multirow[t]{2}{*}{$\mathrm{NaCl}$} & $\begin{array}{c}1.92 \\
(+4.3)\end{array}$ & $\begin{array}{c}1.75 \\
(+257)\end{array}$ & $\begin{array}{c}1.14 \\
(+128)\end{array}$ & $\begin{array}{c}1.27 \\
(+535)\end{array}$ & $\begin{array}{c}1.56 \\
(+184)\end{array}$ & $\begin{array}{c}0.84 \\
(+48.2)\end{array}$ & $\begin{array}{c}1.36 \\
(+3.0)\end{array}$ & $\begin{array}{c}1.10 \\
(+233)\end{array}$ & $\begin{array}{c}0.96 \\
(+9.1)\end{array}$ & $\begin{array}{c}1.22 \\
(+2.5)\end{array}$ & 0.56 \\
\hline & \multicolumn{11}{|c|}{ Catalase: $\mu$ moles $\mathrm{H}_{2} \mathrm{O}_{2}$ decomposed } \\
\hline Control & 1749 & 756 & 791 & 568 & 787 & 720 & 900 & 939 & 711 & 829 & 40.4 \\
\hline $\mathrm{NaCl}$ & $\begin{array}{c}668 \\
(-61.8)\end{array}$ & $\begin{array}{c}709 \\
(-6.3)\end{array}$ & $\begin{array}{c}937 \\
(+18.4)\end{array}$ & $\begin{array}{c}977 \\
(+71.9)\end{array}$ & $\begin{array}{c}740 \\
(-6.1)\end{array}$ & $\begin{array}{c}750 \\
(+4.2)\end{array}$ & $\begin{array}{l}894 \\
(-0.7)\end{array}$ & $\begin{array}{c}816 \\
(+13.1)\end{array}$ & $\begin{array}{c}654 \\
(-8.0)\end{array}$ & $\begin{array}{c}659 \\
(-20.4)\end{array}$ & 36.2 \\
\hline
\end{tabular}

Figures in parenthesis denote $\%$ increase or decrease over respective control 


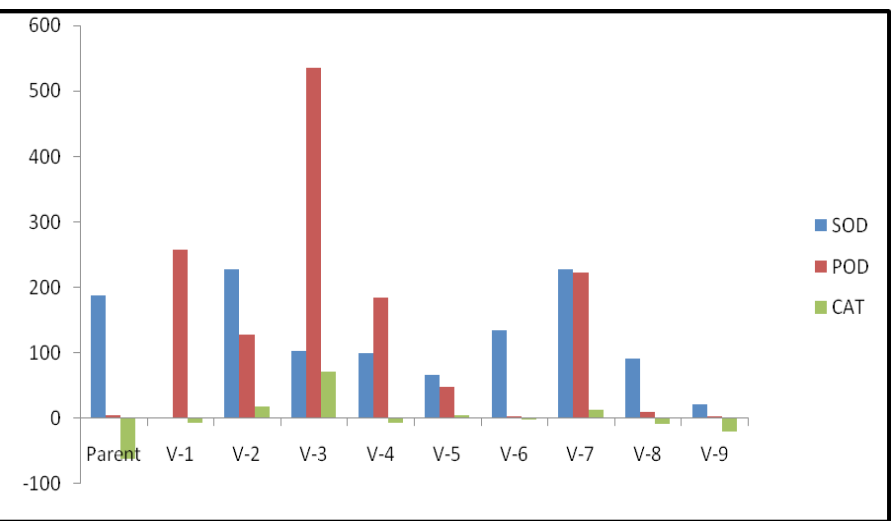

Figure 1: Percentage increase /decrease over respective control in different biochemical parameters after $4^{\text {th }}$ day of treatment.

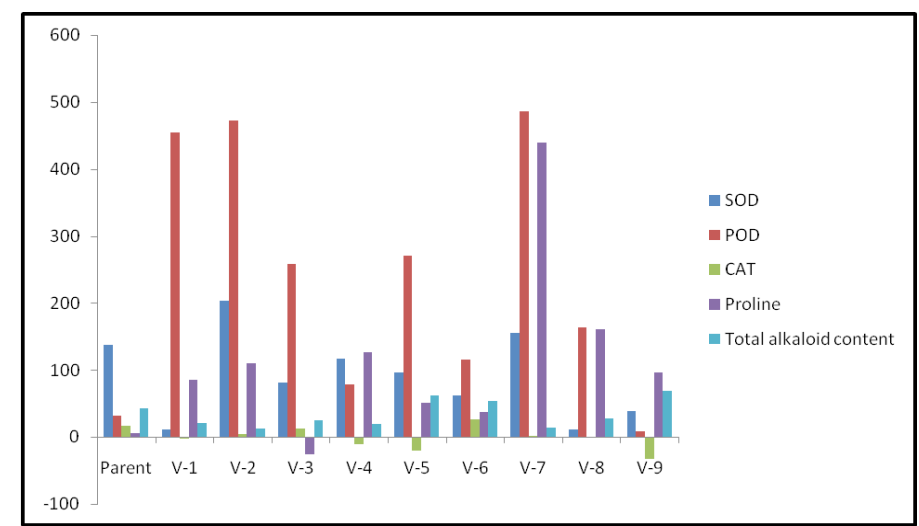

Figure 2: Percentage increase /decrease over respective control in different biochemical parameters after $8^{\text {th }}$ day of treatment.

Table 3: Activity of antioxidative enzymes in C. roseus leaves in relation to excess $\mathrm{NaCl}$ supply at day 8.

\begin{tabular}{|c|c|c|c|c|c|c|c|c|c|c|c|}
\hline $\begin{array}{l}\text { Treatments/ } \\
\text { Variants }\end{array}$ & Parent & V1 & V2 & V3 & V4 & V5 & V6 & V7 & V8 & V9 & $\begin{array}{c}\text { LSD } \\
P=0.05\end{array}$ \\
\hline & \multicolumn{11}{|c|}{ Superoxide dismutase: $\mathrm{EU}$} \\
\hline Control & 20.4 & 16.8 & 17.0 & 16.6 & 21.1 & 24.3 & 34.8 & 24.9 & 42.0 & 24.9 & 17.7 \\
\hline \multirow[t]{3}{*}{$\mathrm{NaCl}$} & 48.6 & 18.6 & 51.4 & 29.7 & 45.7 & 50.8 & 56.6 & 63.5 & 46.8 & 34.5 & 23.7 \\
\hline & $(+138)$ & $(+11.2)$ & $(+203)$ & $(+81)$ & $(+117)$ & $(+96.8)$ & $(+62.5)$ & $(+155)$ & $(+11.3)$ & $(+38.7)$ & \\
\hline & \multicolumn{11}{|c|}{ Peroxidase: Difference in OD } \\
\hline Control & 0.64 & 0.34 & 0.56 & 0.53 & 1.18 & 0.63 & 0.83 & 0.83 & 1.18 & 1.76 & 0.52 \\
\hline \multirow[t]{3}{*}{$\mathrm{NaCl}$} & 2.63 & 1.89 & 3.21 & 1.87 & 2.10 & 2.28 & 1.79 & 4.87 & 3.11 & 1.92 & 1.02 \\
\hline & $(+31.1)$ & $(+455)$ & $(+473)$ & $(+258)$ & $(+78)$ & $(+270)$ & $(+116)$ & $(+486)$ & $(+164)$ & $(+9.1)$ & \\
\hline & \multicolumn{11}{|c|}{ Catalase: $\mu$ moles $\mathrm{H}_{2} \mathrm{O}_{2}$ decomposed } \\
\hline Control & 1115 & 731 & 849 & 679 & 719 & 744 & 1008 & 943 & 919 & 724 & 51.5 \\
\hline \multirow[t]{2}{*}{$\mathrm{NaCl}$} & 1307 & 709 & 883 & 765 & 639 & 694 & 742 & 960 & 916 & 488 & 68.4 \\
\hline & $(+17.1)$ & $(-2.6)$ & $(+4.0)$ & $(+12.5)$ & $(-11.2)$ & $(-20.2)$ & $(-26.4)$ & $(+1.9)$ & $(-0.3)$ & $(-32.6)$ & \\
\hline
\end{tabular}

Figures in parenthesis denote $\%$ increase or decrease over respective control

Table 4: Proline and total alkaloid in C. roseus leaves in relation to excess $\mathrm{NaCl}$ supply at day 8.

\begin{tabular}{|c|c|c|c|c|c|c|c|c|c|c|c|}
\hline $\begin{array}{l}\text { Treatments / } \\
\text { Variants }\end{array}$ & Parent & V1 & V2 & V3 & V4 & V5 & V6 & V7 & V8 & V9 & $\begin{array}{c}\text { LSD } \\
P=0.05\end{array}$ \\
\hline & \multicolumn{11}{|c|}{ Proline: $\mu \mathrm{g}$ proline $/ 100 \mathrm{mg}$ fresh weight } \\
\hline Control & 60.0 & 53.0 & 50.0 & 50.0 & 47.0 & 48.0 & 30.5 & 21.5 & 27.5 & 29.0 & 31.2 \\
\hline \multirow[t]{2}{*}{$\mathrm{NaCl}$} & $\begin{array}{c}63.5 \\
(+5.83)\end{array}$ & $\begin{array}{c}72.0 \\
(+84.8)\end{array}$ & $\begin{array}{c}105.5 \\
(+110)\end{array}$ & $\begin{array}{c}63.0 \\
(26.3)\end{array}$ & $\begin{array}{l}106.0 \\
(+126)\end{array}$ & $\begin{array}{c}72.0 \\
(+50.7)\end{array}$ & $\begin{array}{c}42.0 \\
(+37.7)\end{array}$ & $\begin{array}{c}116.0 \\
(+439)\end{array}$ & $\begin{array}{c}72.0 \\
(+161)\end{array}$ & $\begin{array}{c}57.0 \\
(+96.6)\end{array}$ & 26.0 \\
\hline & \multicolumn{11}{|c|}{ Total alkaloid: $\mu \mathrm{g} / \mathrm{g}$ dry weight } \\
\hline Control & 74.0 & 84.0 & 100.0 & 80.0 & 72.0 & 73.0 & 60.0 & 87.5 & 85.0 & 84.0 & 52.2 \\
\hline $\mathrm{NaCl}$ & $\begin{array}{c}106.0 \\
(+43.2)\end{array}$ & $\begin{array}{c}102.0 \\
(+21.4)\end{array}$ & $\begin{array}{c}114.0 \\
(+12.3)\end{array}$ & $\begin{array}{l}100.0 \\
(+25)\end{array}$ & $\begin{array}{c}86.0 \\
(+19.4)\end{array}$ & $\begin{array}{c}118.0 \\
(+61.6)\end{array}$ & $\begin{array}{c}92.0 \\
(+53.3)\end{array}$ & $\begin{array}{c}100.0 \\
(+14.3)\end{array}$ & $\begin{array}{c}108.0 \\
(+27.1)\end{array}$ & $\begin{array}{r}100.0 \\
(+69.1)\end{array}$ & 77.4 \\
\hline
\end{tabular}

Figures in parenthesis denote $\%$ increase or decrease over respective control

variant V2, V3 and V7 (Table 2 and 3) which suggesting the existence of an effective scavenging mechanism to remove ROS.

Moreover, catalase activity was also found to be increased in variants V2, V3 and V7 with the salt application. Proline content was increased in the leaves of all variants with the salt supply which was found to be higher in variants V2 and V7 (Table 4).

\section{DISCUSSION}

An increase in the activities of superoxide dismutase and peroxidase was found in all the variants supplied with $200 \mathrm{mM} \mathrm{NaCl}$ but it was more prominent in variants V2 and V7. Similar response to $\mathrm{NaCl}$ supply was reported in rice cultivars. ${ }^{17,18}$ 
The reduction in foliar SOD activity under high salinity can be also a consequence of an altered synthesis and accumulation of less active enzymes ${ }^{18}$ and/or of a higher turnover of SODs. ${ }^{19}$ The increase in POD activity under salt stress condition also observed in several plant spe$\mathrm{cies}^{20}$ and might be attributed to rapid diffusion of $\mathrm{H}_{2} \mathrm{O}_{2}$ production in the cytosol or due to accumulation of high levels of phenols and reduced protein formation. ${ }^{21}$ Hernandz et al. ${ }^{22}$ reiterated that increase in the activities of SOD and POD was found more in the salt tolerant cultivars. Moreover, CAT activity was also increased in V2, V3 and V7 with the salt application. Similar results have earlier been reported in rice $^{17}$ and Raphanus sativa. ${ }^{23}$ Higher catalase activity might help in protecting the membranes from lipid peroxidation due to destruction of $\mathrm{H}_{2} \mathrm{O}_{2}$ which is a toxic metabolite produced by dismutation of superoxide radical by SOD. Proline content increased in leaves of all the variants with the salt supply which was found to be higher in variants V2 and V7. The enhancement in proline content under salt stress conditions has been reported to be a signal of water stress and the salt tolerance because proline can be considered as a compound which reduces the nitrogen and carbon skeleton for stress recovery. ${ }^{24}$ According to Rossa-Iberra and Maiti ${ }^{25}$ the increase in proline is probably due to the capacity of some plants to accumulate organic (sucrose, glucose) and inorganic $(\mathrm{Na}, \mathrm{K}, \mathrm{Cl})$ metabolites in the cytoplasm to reduce the water potential and change in osmotic gradient, assuring the water flow to the plant and hereby the increased tolerance. $\mathrm{NaCl}$ supply also enhanced the alkaloid content in consonance with that of the report of Karadye and Gaikwad ${ }^{9}$ in C. roseus.

\section{CONCLUSION}

Although in our results variation in enzyme activity and other mentioned parameters were noted for all the variants but in conclusion the variants $\mathrm{V} 2, \mathrm{~V} 3$ and $\mathrm{V} 7$ of $C$. roseus exhibiting higher activities of antioxidant enzymes with more proline content this indicates they contain better survival potential against salt stress condition because higher level of these enzymes minimize the effect of ROS generated as a effect of salt stress condition, are highly reactive in absence of any protective mechanism and they can seriously disrupt normal metabolism through oxidative damage to membrane lipids, proteins, pigments and nucleic acids due to which survival of plant is not possible. These variants will be used for developing the salt tolerant genotypes in Catharanthus roseus.

\section{ACKNOWLEDGEMENT}

Thanks are due to the Director, CSIR-CIMAP, Lucknow and Officer inCharge All India co-ordinated Project on Micronutrient, Botany Dept., Lucknow University for extending the help for various analysis.

\section{CONFLICT OF INTEREST}

The author declares no conflict of interest.

\section{ABBREVIATIONS}

ROS: Reactive oxygen species; SOD: Superoxide dismutase; POD: Peroxidase; CAT: Catalase.

\section{REFERENCES}

1. Mittler R. Oxidative stress, antioxidants and stress tolerance. Trends in Plant Sci. 1995; 7(9):405-10.

2. Neill S, Desikan R, Hancock J. Hydrogen peroxide signaling. Curr Opin Plant Biol. 2002;5(5):388-95.

3. Imlay JA. Pathways of oxidative damage. Annu Rev Microbiol. 2003;57(1):395418.

4. Vranova E, Inze D, Brensegem FV. Signal transduction during oxidative stress. J Exp Bot. 2002;53(372):1227-36.

5. Srivalli B, Chinnusamy V, Chopra RK. Antioxidant defense in response to abiotic stresses in plants. J Plant Biol. 2003;30(2):121-39.

6. Prochazkova D, Sairam RK, Srivastava GC, Singh DV. Oxidative stress and antioxidant activity as the basis of senescence in maize leaves. Plant Sci. 2001;161(4):765-71.

7. Asada K. The water-water cycle in chloroplasts: Scavenging of active oxygen and dissipation of excess photons. Annu Rev Plant Physiol Plant Mol Biol. 1999;50(1):601-39.

8. Jaleel CA, Gopi R, Alagu LGM, Panneerselvam R. Triadimefon induced changes in the antioxidant metabolism and ajmalicine production in Catharanthus roseus (L.) G. Don. Plant Sci. 2006;171(2)271-6.

9. Karadge BA, Gaikwad PV. Influence of sodium chloride salinity on growth and organic constituents of Catharanthus roseus (L.) G. Don. Indian J Plant Physiol. 2003;8(4):392-7.

10. Hewitt EJ. Sand and water culture methods used in the study of Plant Nutrition. Commonwelth Agricultural Bureaux, Farnham Royal Buck, UK. 1968.

11. Beauchamp C, Fridovich I. Superoxide dismutase: Improved assays and an assay applicable to acrylamide gels. Anal Biochem. 1971;44(1):276-83.

12. Luck H, Bergmeyer HV. Peroxidase In: Methods in enzymatic analysis. Academic Press, Inc. New York. 1963;895-7.

13. Euler HV, Josephson K. Katalase UI. Leibigs. Ann Chem. 1927;452:158-87.

14. Lowry OH, Rosenbrough NJ, Farr AL, Randall RJ. Protein measurement with Folin Phenol reagent. J Biolog Chem.1995;193(1):265-75.

15. Bates $P E$, Weatherley $E$. A re-examination of the relative turgidity technique for estimating water deficit in leaves. Australian J Biolog Sci. 1973;15(413):413-28.

16. Narasimhan S, Mehrotra S. Spectrophotometric method for estimation of alkaloid-precipitable with Dragendroff's reagent in plant materials. Journal AOAC Int. 2003;86(6):1124-27.

17. Pal M, Singh DK, Rao LS, Singh KP. Photosynthetic characteristics and activity of antioxidant enzymes in salinity tolerant and sensitive rice cultivars. Indian $\mathrm{J}$ Plant Physiol. 2004;9(4);407-12.

18. Dionisio-Sese ML, Tobita S. Antioxidant responses of rice seedling to salinity stress. Plant Sci. 1998;135(1):1-9.

19. Chaparzadeh N, Amico ML, Nejad RK, Izzo R, Izzo FN. Antioxidative responses of Calendula officinalis under salinity conditions. Plant Physiol Biochem. 2004;42(9):695-701.

20. Luna CM, Gonjalez CA, Trippi VS. Oxidative damage caused by an excess of coppar in oat leaves. Plant Cell Physiol. 1994;35(1):11-15.

21. Marschner $\mathrm{H}$. Miniral nutrient of higher plants. Academic Press, New York. 1995;889

22. Hernadez JA, Jimenez A, Mullineausx P, Sevillia F. Tolerance of Pea (Pissum sativum L.) to long term salt stress in associated with induction of antioxidant defenses. Plant Cell Environ. 2000;23:853-62.

23. Muthukumarasamy M, Dutta SG, Panneerselvam R. Enhancement of peroxidase, polyphenol oxidase and superoxide dismutase activities by triadimefon in $\mathrm{NaCl}$ stressed Raphanus sativus L. Biol Plant. 2000;43(2):317-20.

24. Bera AK, Pati MK, Bera A. Bressinolide ameliorates adverse affects of salt stress on germination and seedling growth of rice. Indian J Plant Physiol. 2006;11(2):182-9

25. Rossa-lbarra MDL, Maiti KK. Biochemical mechanism in glossy Sorghum lines for resistance to salinity stress. J Plant Physiol. 1995;146(4):515-9. 


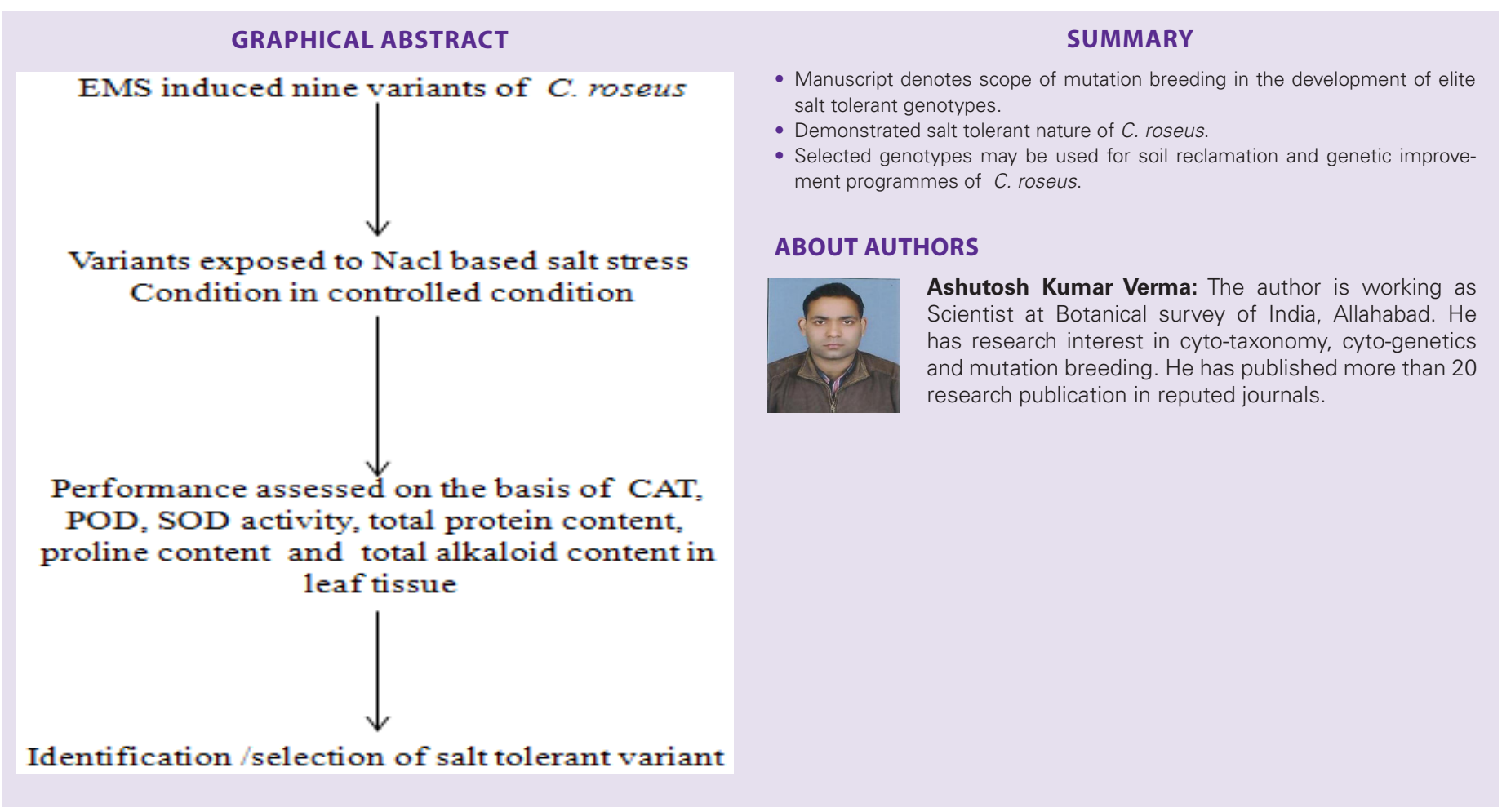

Cite this article: Verma AK. Study of Relative Antioxidant Potential of Induced Variants of Catharanthus roseus (L.) G. Don in Salt Stress Condition for the Effective Selection of Salt Tolerant Variant. Free Radicals and Antioxidants. 2019;9(2):73-7. 